\title{
Expression of reg protein in rat regenerating islets and its co-localization with insulin in the Beta cell secretory granules
}

\author{
K. Terazono ${ }^{1}$, Y. Uchiyama ${ }^{2}$, M. Ide ${ }^{3}$, T. Watanabe ${ }^{1}$, H. Yonekura $^{1}$, H. Yamamoto ${ }^{1}$ and H. Okamoto ${ }^{1}$ \\ Department of Biochemistry, Tohoku University School of Medicine, Sendai \\ 2 Department of Anatomy, Institute of Basic Medical Sciences, University of Tsukuba, Tsukuba, and \\ ${ }^{3}$ Shionogi Research Laboratories, Osaka, Japan
}

\begin{abstract}
Summary. Regenerating islets can be induced by the administration of poly(ADP-ribose) synthetase inhibitors to $90 \%$ depancreatized rats. In screening a regenerating isletderived cDNA library, we previously isolated a novel gene, reg (regenerating gene), which encodes a 165 -amino acid protein with a 21 -amino acid signal sequence. In the present study, we have examined the expression and localization of reg protein in the regenerating islets by immunocytochemical techniques using a monoclonal antibody against a recombinant rat reg protein of 144 amino acids without the signal sequence. Light microscopy examination showed strong immunoreactivity for reg protein in the regenerating islets of the rats at two weeks and two months after the $90 \%$ pancreatectomy, whereas reg protein was almost undetectable in nor-
\end{abstract}

mal rat islets or in the islets of the rats one year after the pancreatectomy. Almost all the reg protein-positive cells were stained for insulin. By applying the immunogold technique at the ultrastructural level, it was demonstrated that both reg protein and insulin occur in the central granular core of the regenerating Beta cell secretory granules. These results suggest that reg protein is synthesized in and secreted from the regenerating Beta cells and that its expression is closely associated with Beta-cell regeneration.

Key words: Reg protein, regenerating islet, poly(ADPribose) synthetase inhibitor, insulin, secretory granule, pancreatic stone protein, immunocytochemistry.
We have previously demonstrated that administration of poly(ADP-ribose) synthetase inhibitors such as nicotinamide to $90 \%$ depancreatized rats induces regeneration of pancreatic islets, thereby preventing the development of diabetes in the rat $[1,2]$. In screening a regenerating isletderived cDNA library, we identified a novel gene, named reg (regenerating gene) $[3,4]$. Northern blot analysis indicated that the gene was activated in rat regenerating islets and in hyperplastic islets of aurothioglucose-treated mice but not in normal islets, suggesting possible roles for this gene in the replication, growth, and maturation of islet cells $[3,4]$. The 165 -amino acid protein encoded by reg had a putative 21-amino acid signal sequence at the amino terminus, suggesting that the gene product is a secretory protein. In this report, we have examined the expression and localization of the reg protein in the regenerating islets of $90 \%$ depancreatized and nicotinamide-treated rats using immunocytochemical techniques.

\section{Materials and methods}

Male Wistar rats (180-200 g) were 90\% depancreatized under diethyl ether anaesthesia, and, beginning seven days before the pancreatectomy and continuing postoperatively for up to one year, received intraperitoneal injections of nicotinamide at a dose of $0.5 \mathrm{~g} / \mathrm{kg}$ body weight daily [1]. The materials used were taken from the remaining pancreases of the $90 \%$ depancreatized and nicotinamidetreated rats and from normal rat pancreases. A recombinant DNA rat reg protein corresponding to positions 22-165 of the deduced rat reg protein [3] was synthesized in Saccharomyces cerevisiae strain $\mathrm{AH} 22$, and a mouse anti-reg protein monoclonal antibody was raised against it; the antibody was proved to be monospecific for reg protein by Western blot analysis (data not shown).

For light microscopy, the tissues were freeze-dried at $-35^{\circ} \mathrm{C}$ for $72 \mathrm{~h}$, fixed by vapor-phase paraformaldehyde at $80^{\circ} \mathrm{C}$ for $1 \mathrm{~h}$, and embedded in Epon 812 [5]. Serial semi-thin sections were cut at $1 \mu \mathrm{m}$ with an LKB ultramicrotome No. IV (LKB-Produkter AB, Bromma, Sweden). Semi-thin sections were immunostained [5] either with a mouse anti-reg protein $(1: 500)$ and then with a biotinylated horse anti-mouse $\operatorname{IgG}(1: 100$; Vector, Burlingame, Calif., USA), or with a guinea pig anti-insulin (1:1000; DAKO, Santa Barbara, Calif., USA) and then with a biotinylated goat anti-rabbit IgG $(1: 100$; Vector). Immunostained sections were viewed with a Nomarski differential interference contrast microscope (Olympus, Tokyo, Japan).

For electron microscopy, animals anaesthesized with pentobarbital were perfused with $154 \mathrm{mmol} / \mathrm{l} \mathrm{NaCl}$ and then with $0.5 \%$ glutaraldehyde $-4 \%$ paraformaldehyde buffered with $0.1 \mathrm{~mol} / \mathrm{l}$ cacodylate$\mathrm{HCl}, \mathrm{pH} 7.2$, and pancreases excised were fixed and embedded as described previously [5]. Ultramicrotome cut thin sections were incubated [5] with anti-reg protein $(1: 160)$ and anti-insulin $(1: 200)$ as the first antibodies, and gold-labelled horse anti-mouse IgG (gold particle $15 \mathrm{~nm}$ in diameter) and gold-labelled goat anti-rabbit IgG (gold particle $8 \mathrm{~nm}$ in diameter) as the second antibodies; size adjustment and labelling of colloidal gold particles were performed according to the method of Slot and Geuze [6]. For the double immunostaining, the two-face technique as described by Bendayan was used [7]. After the immunostaining, sections were stained with a saturated aqueous solution of uranyl acetate and lead citrate and were observed with a Hitachi H-600 electron microscope (Hitachi Ltd., Tokyo, Japan). 

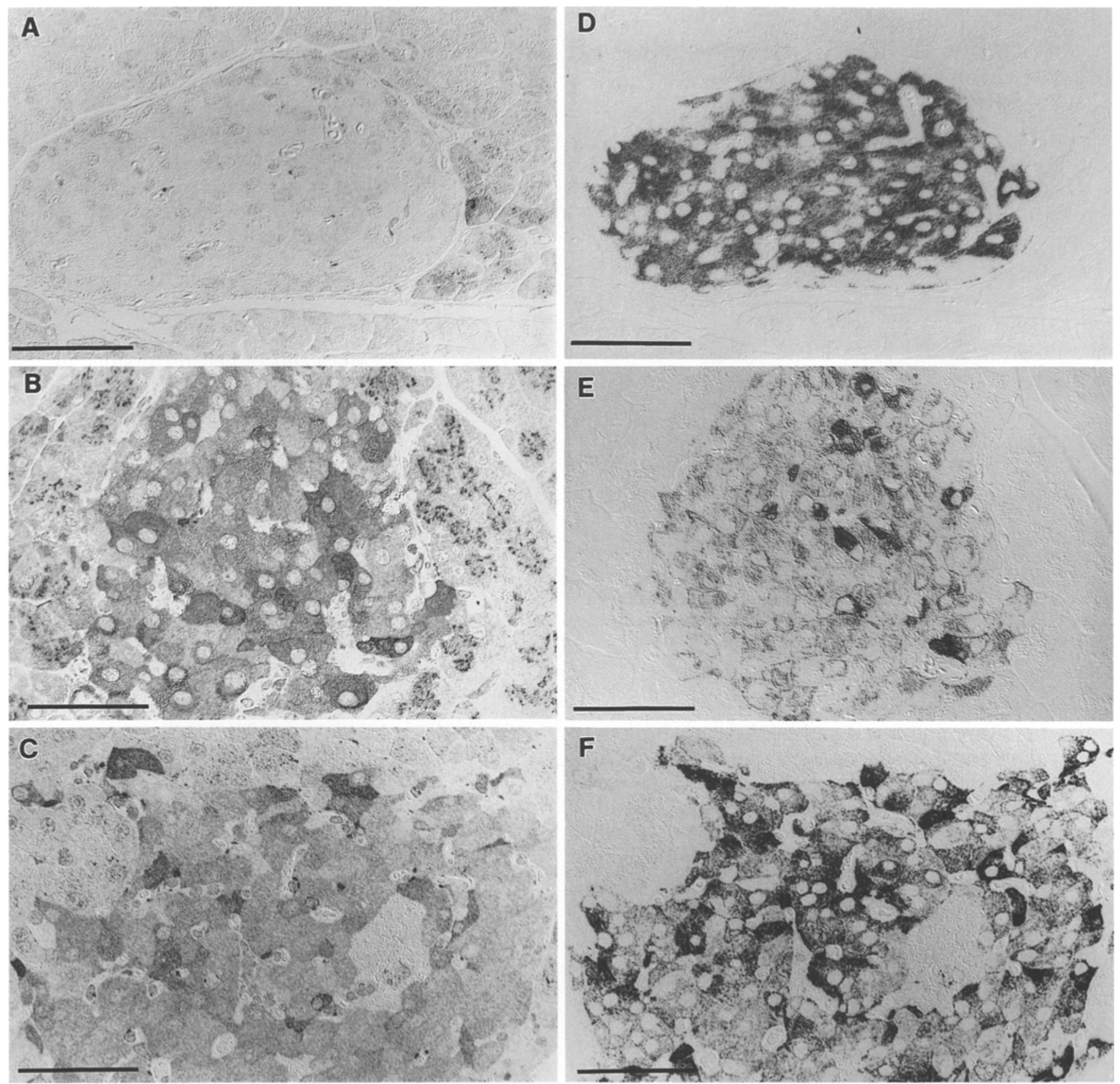

Fig. 1 A-F. Serial semi-thin sections showing immunocy tochemical localization of reg protein (A-C), and insulin (D-F). Pancreas from normal rat $(\mathbf{A}, \mathbf{D})$. Pancreas from nicotinamide-treated rat two weeks after $90 \%$ pancreatectomy (B, E); 2 months after the operation $(\mathbf{C}, \mathbf{F})$. Bar $=100 \mu \mathrm{m}$

\section{Results and discussion}

As shown in Fig. 1 B and C, almost the entire area of the islets in the remaining pancreases of $90 \%$ depancreatized and nicotinamide-treated rats were densely stained for reg protein two weeks and two months after the operation. The reg protein was distributed throughout the cytoplasm of each islet cell. One year after the operation (data not shown) the islets were scarcely stained for reg

protein, similar to those of normal untreated rats (Fig. 1A). Semi-thin sections incubated with the anti-reg protein antibody absorbed by the recombinant DNA rat reg protein showed no specific reaction deposits in regenerating islet cells (data not shown).

When the serial semi-thin sections were incubated with an anti-insulin antibody, almost all the cells stained for reg protein were positively stained for insulin (Fig. 1 E and F). Two weeks after the operation (Fig. 1E) islet cells showed relatively weak immunoreactivity for insulin, and at two months (Fig. 1F) and one year (data not shown) after the operation exhibited an immunoreactivity comparable with that of normal islet cells (Fig. 1D). This suggests that it takes several weeks for the regenerated Beta cells to store considerable amounts of insulin. 


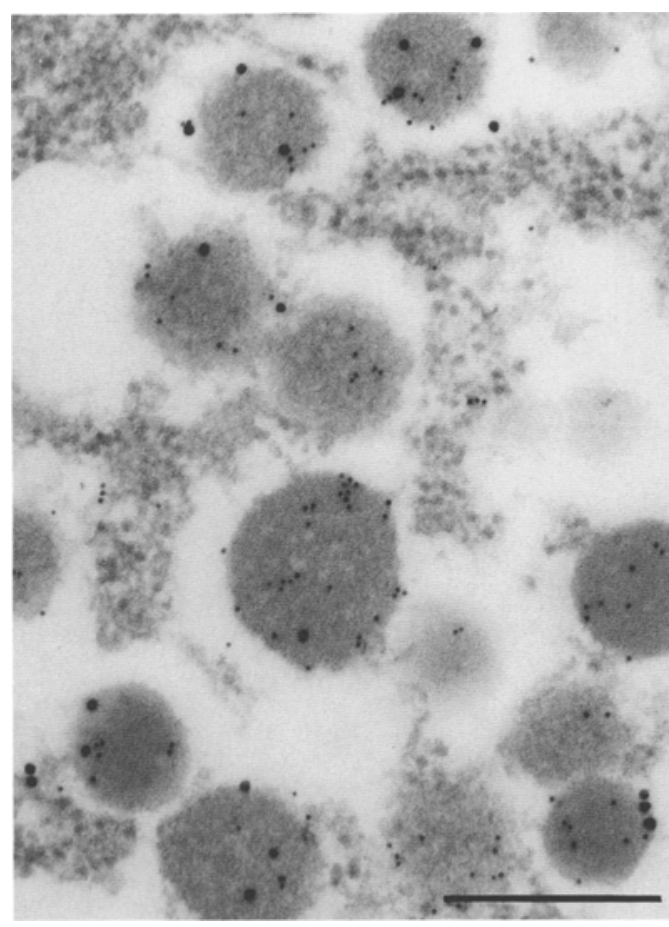

Fig. 2. Double immunocytochemical staining of insulin (small gold particles) and reg protein (large gold particles) in regenerating Beta cell of rat two weeks after $90 \%$ pancreatectomy. Bar $=500 \mathrm{~nm}$

In the electron microscope double labelling experiments, the $15 \mathrm{~nm}$ and $8 \mathrm{~nm}$ gold markers used for the identification of the subcellular localizations of reg protein and insulin respectively were almost exclusively found in the secretory granules of the regenerating Beta cells of the rats two weeks after the operation; both the large and small gold particles were co-localized in the electron-dense central core of the granules, leaving the peripheral electron lucent space unlabelled (Fig.2). The reg protein was only rarely encountered in the secretory granules of normal Beta cells (data not shown).

In the preceding paper we described the cloning and sequencing of a cDNA derived from rat pancreatic islets following partial pancreatectomy and poly(ADP-ribose) synthetase inhibitor-treatment $[3,4]$. On the basis of its origin in regenerating islets the gene was named reg (regenerating gene). In this paper we have demonstrated the existence of the reg product in rat regenerating islets by immunocytochemical techniques using a monoclonal antibody against recombinant DNA rat reg protein. Intense immunoreactivity to reg protein in the pancreatic islets was observed at two weeks and two months after the partial pancreatectomy but not at one year after the operation; this result was compatible with the previous observation that the reg mRNA content in RNA from islets increased up to three months after the operation and then decreased to an almost undetectable level at one year after the operation [3]. Almost all the reg protein-positive cells in the islets were stained for insulin. The findings under electron microscopy clearly indicated that both reg protein and insulin occur in the electron-dense central core of the regenerating Beta cell secretory granules. The occurrence of reg protein in the islet Beta cells and its co- localization with insulin in the secretory granules suggested that reg protein is synthesized in the regenerating Beta cells and can be co-released with insulin from the Beta cells on stimulation.

A human homologue to reg was also isolated from a human pancreas-derived cDNA library [3, 4]. Recently it was noticed [8] that human reg encodes pancreatic stone protein the existence of which has previously been observed only in human exocrine pancreases [9]. A 144amino acid protein corresponding to positions $22-165$ of the deduced human reg protein [3] is comparable to the form of pancreatic stone protein sequenced by De Caro et al. [10]. The present study has shown immunoreactivity in exocrine cells for rat reg protein as well (Fig. 1 A-C). This suggests that rat equivalents of pancreatic stone protein exist in exocrine cells of both the normal rat pancreas and the remaining pancreases of partially depancreatized and nicotinamide-treated rats.

Acknowledgements. This work was supported in part by grants-inaid for Scientific Research from the Ministry of Education, Science and Culture, Japan.

\section{References}

1. Yonemura Y, Takashima T, Miwa K, Miyazaki I, Yamamoto H, Okamoto H (1984) Amelioration of diabetes mellitus in partially depancreatized rats by poly(ADP-ribose) synthetase inhibitors: evidence of islet B-cell regeneration. Diabetes 33: 401-404

2. Okamoto H (1985) Molecular basis of experimental diabetes: degeneration, oncogenesis and regeneration of pancreatic Bcells of islets of Langerhans. Bioessays 2: 15-21

3. Terazono K, Yamamoto H, Takasawa S, Shiga K, Yonemura Y, Tochino Y, Okamoto H (1988) A novel gene activated in regenerating islets. J Biol Chem 263: 2111-2114

4. Terazono K, Watanabe T, Yonemura Y (1990) A novel gene, reg, expressed in regenerating islets. In: Okamoto $\mathrm{H}$ (ed) Molecular biology of the islets of Langerhans. Cambridge University Press, Cambridge, pp 301-313

5. Watanabe M, Watanabe T, Ishii $\mathrm{Y}$, Matsuba $\mathrm{H}$, Kimura $\mathrm{S}$, Fujita T, Kominami E, Katunuma N, Uchiyama Y (1988) Immunocytochemical localization of cathepsins $\mathrm{B}, \mathrm{H}$, and their endogenous inhibitor, cystatin $\beta$, in islet endocrine cells of rat pancreas. J Histochem Cytochem 36: 783-791

6. Slot JW, Geuze HJ (1985) A new method of preparing gold probes for multiple-labelling cytochemistry. Eur J Cell Biol 38 : $87-93$

7. Bendayan M (1982) Double immunocytochemical labelling applying the protein A-gold technique. J Histochem Cytochem 30 : $81-85$

8. Stewart TA (1989) The human reg gene encodes pancreatic stone protein. Biochem J 260: 622-623

9. Lechene De La Porte P, De Caro A, Lafont H, Sarles H (1986) Immunocytochemical localization of pancreatic stone protein in the human digestive tract. Pancreas 1:301-308

10. De Caro AM, Adrich Z, Fournet B, Capon C, Bonicel JJ, De Caro JD, Rovery M (1989) N-terminal sequence extension in the glycosylated forms of human pancreatic stone protein: the 5-oxoproline $\mathrm{N}$-terminal chain is $O$-glycosylated on the 5 th amino acid residue. Biochim Biophys Acta 994: 281-284

Received: 6 October 1989

and in revised form: 13 November 1989

Prof. H. Okamoto

Department of Biochemistry

Tohoku University School of Medicine

Sendai 980, Miyagi, Japan 